\title{
Right ventricular performance in essential hypertension after beta-blockade
}

\author{
JACK FERLINZ, JOHN L EASTHOPE, DAVID HUGHES, JACK SIEGEL, \\ JONATHAN TOBIS, WILBERT S ARONOW
}

From the Cardiovascular Section, Medical Service, Veterans Administration Medical Center, Long Beach, California; and the University of California School of Medicine, Irvine, Califormia, USA

SUMMARY Recent studies indicate that right ventricular performance is impaired even in uncomplicated systemic hypertension. Because of widespread use of beta-blockade in essential hypertension, it is possible that such treatment often further depresses right ventricular contractility. To test this premise, and to evaluate the changes induced by different beta-adrenoceptor blocking agents on the contractility of right ventricular myocardium, 20 patients with essential hypertension were divided into two groups on a double-blind randomised basis, and maintained on oral oxprenolol or propranolol for five weeks. Cardiac catheterisation and right ventricular cineangiography were performed at the beginning and again at the end of the five week period. Right ventricular end-diastolic volume index did not change significantly in either group. In contrast, right ventricular end-systolic volume index increased, and right ventricular ejection fraction significantly decreased after chronic beta-blockade. Cardiac index decreased in both groups, but these changes were not statistically significant.

When the intergroup differences were compared for all measured indices none of the changes between the two groups was statistically significant. Despite its intrinsic sympathomimetic activity, oxprenolol therefore impairs right ventricular performance to an extent nearly equal to that of propranolol. Moreover, right ventricular contractility is clearly diminished after the institution of beta-blockade in hypertensive patients - an effect that has until now been thought to be limited to the left side of the heart. Great caution must therefore be exercised when beta-blockade is initiated in patients with severely abnormal right ventricular function, because frank right ventricular decompensation may result.

Recent studies in our laboratory have shown a commonly accepted concept-that right ventricular function is normal in uncomplicated systemic hypertension-to be incorrect. Right ventricular performance diminishes even with early abnormal increases in arterial pressure. ${ }^{1}$ Because systemic hypertension is frequently treated with beta-blockade, it was essential to determine how such treatment affects the integrity of the right heart which is already compromised by the hypertension itself.

The effects of beta-blockade on left ventricular performance have been extensively investigated. ${ }^{2-6}$ There is a virtually unanimous agreement that one of the most commonly used beta antagonists, propranolol, depresses left ventricular contractility. ${ }^{7-9}$ More controversy, however, surrounds some of the newer experimental beta-adrenergic blocking agents, especially those that

Received for publication 5 September 1980 possess intrinsic sympathomimetic activity. Moreover, the effects on right ventricular performance generated by beta-blockers with or without intrinsic sympathomimetic activity are still completely unknown.

Oxprenolol, which is still not approved for general clinical use in the United States, possesses intrinsic sympathomim atic activity. ${ }^{10-13}$ When the drug is used intravenously, this activity is said to minimise the negative inotropic effects on the left ventricle characteristic of beta-blocking agents, ${ }^{14-16}$ while antihypertensive $^{17}$ and antianginal ${ }^{18-21}$ effects are retained. In order to compare the effects of long term oral administration of oxprenolol on right ventricular function and haemodynamics with the effects generated by an established beta-antagonist without intrinsic sympathomimetic activity, propranolol, ${ }^{22} 23$ we performed a five week, double-blind randomised study on 20 patients with uncomplicated essential hypertension who were maintained on equipotent oxprenolol or 
propranolol regimens. The study was specifically designed to compare the haemodynamic and right ventricular effects of the two drugs over a prolonged period, to evaluate the changes induced by different beta-blocking drugs on right ventricular volumes and ejection fraction in essential hypertension, and to determine if oxprenolol is truly a lesser cardiac depressant than propranolol.

\section{Methods}

Twenty patients with uncomplicated essential hypertension (having outpatient diastolic blood pressures above $100 \mathrm{mmHg}$ and below $125 \mathrm{mmHg}$ ) were selected for this study. All gave informed consent, were subsequently randomised into two 10 patient groups, and were then maintained on a five week equipotent oxprenolol or propranolol regimen on a double-blind basis. The design of the study is shown in Fig. 1, with oxprenolol patients representing group $\mathrm{O}$, and propranolol patients group P. Right heart cardiac catheterisation which included right ventricular cineangiography was performed before and at the end of the five week beta-blockade.

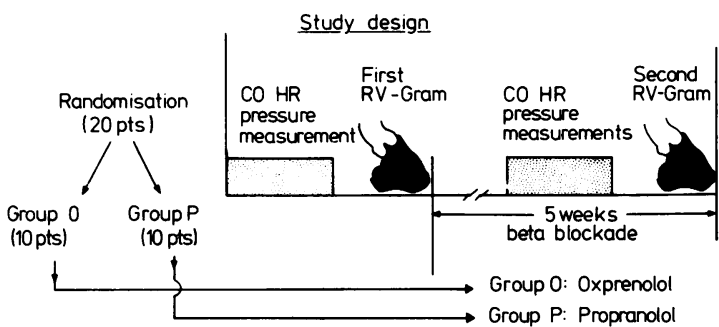

Fig. 1 The design of the study. The experiment was performed in a double-blind manner, so that the composition of the two groups therefore occurred only after the study was completed, and the drug code became known.

The clinical profiles of the two patient populations were comparable. None of the patients had a history of coronary or cerebrovascular disease, pulmonary disorders, congestive heart failure, or significant valvular or congenital lesions. All subjects were in normal sinus rhythm without any conduction abnormalities. The mean age of patients in the oxprenolol group was $49 \pm 11$ years, and in the propranolol group $54 \pm 4$ years ( $p$ not significant). Age-related changes in response to betablockade $^{24}$ therefore had little or no effect on the results of this study. Five patients in the oxprenolol group and two patients in the propranolol group had electrocardiographic evidence of left ventricular hypertrophy. No other electrocardiographic abnormalities were present in any of the patients. Cardiomegaly (defined as a cardiothoracic ratio of $\geq 0.50$ on a standard posteroanterior chest $x$-ray film) was absent in all patients.
Some of the patients were receiving antihypertensive drugs; these were stopped at least two weeks before the study. Close monitoring of these patients was instituted after the antihypertensive medications were discontinued in order to detect immediately any potentially dangerous acceleration of hypertension but none occurred. Thus, no patients had to be excluded from the study because the withdrawal of drugs was poorly tolerated, and none was withdrawn because of adverse reactions caused by 'beta-blockade. Moreover, no patients had to be reinstated on the original antihypertensive treatment because the beta-adrenergic antagonists failed effectively to control raised blood pressures.

Oxprenolol or propranolol therapy was started with daily doses of $240 \mathrm{mg}$ divided into three aliquots. Identical initial doses for both beta-adrenergic antagonists were used because it has been shown that oxprenolol is approximately equipotent with propranolol. ${ }^{25}$ Dosage was subsequently titrated in increments or decrements of $\mathbf{4 0} \mathrm{mg}$ to achieve the following objectives: resting diastolic blood pressure had to be reduced by at least $10 \mathrm{mmHg}$, and resting heart rate maintained above 50 beats per minute. All patients fulfilled these criteria without any adverse side effects.

The means of three supine blood pressures and heart rates were recorded for all patients at the beginning (the control period), and thereafter at weekly clinic visits until the completion of the study. Supine readings were selected because cardiac catheterisation was also performed in the supine position. Right heart cardiac catheterisation and right ventricular cineangiography were performed, with patients fasting but without sedation, before drug therapy was started and again after the completion of the five week beta-blockade. Cardiac output and pressure data were collected before the right ventriculograms. Cardiac output (CO) was determined with the Lyons indocyanine green indicator-dilution computer by averaging four sequential measurements. All pressures-arterial (AP) systolic, diastolic, and mean; right ventricular systolic and enddiastolic; mean right atrial (RAP); mean pulmonary artery (PAP); and mean pulmonary capillary wedge pressure (PCWP) - were measured over three respiratory cycles with Statham P23Db strain gauges and an Electronics for Medicine DR-12 Simultrace recorder. Heart rate was monitored throughout the study. In addition, systemic vascular resistance $(S V R=[$ mean $\mathrm{AP}$-mean RAP]/CO) and pulmonary vascular

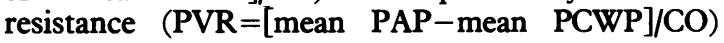
were calculated for each patient.

Single plane cine right ventriculograms in $30^{\circ}$ right anterior oblique projection were performed in all 20 patients. Fifty-five to $65 \mathrm{ml}$ of $76 \%$ meglumine sodium diatrizoate (Renografin 76 ) were injected over a three 
second interval into the right ventricular chamber through a No. 8 Eppendorf or NIH catheter, and right ventriculograms recorded at 64 frames per second on $35 \mathrm{~mm}$ Ilford Cinegram F film with Philips 9 inch image intensifier. The first six beats after complete opacification were analysed by two independent observers; their results showed only a negligible variance. If a premature ventricular contraction was encountered, at least two successive normal sinus beats had to occur before a frame was selected for volumetric analysis. Right ventricular volumes were determined using the method for single plane measurements previously developed in our laboratory. ${ }^{26}$ End-diastolic volume index (EDVI), end-systolic volume index, stroke volume index (SVI), and ejection fraction $(\mathrm{EF}=$ SVI/EDVI) were calculated for each patient.

Chest $x$-ray films (posteroanterior and lateral) and electrocardiograms were obtained before and after beta-blockade. Blood samples for plasma renin activity were collected from all patients just before each cardiac catheterisation. All subjects were kept on their normal sodium diets, and were instructed to stand for three hours before their blood was drawn for the plasma renin activity determination. Plasma renin activity was measured by radioimmunoassay ${ }^{27}$ (Bio-Science Laboratories). Two blood samples for plasma oxprenolol or propranolol concentration were drawn during the second cardiac catheterisation. The first sample was collected 90 minutes from the time of drug ingestion, and the second sample 30 minutes later. This timing for the blood collection was selected because it has been shown that the peak effect of orally administered propranolol occurs between 90 and 120 minutes after the ingestion of the drug, ${ }^{28-30}$ and that the plasma half-life of oxprenolol resembles that of propranolol..$^{31}{ }^{32}$ The blood sample collections took place concurrently with the measurements of haemodynamic indices. Plasma oxprenolol levels were determined by gas-liquid chromatography $^{33}$ (Ciba-Geigy), and plasma propranolol levels by high pressure liquid chromatography $^{34}$ (Bio-Science Laboratories). The results of the first and second blood sample obtained during the second cardiac catheterisation were combined and averaged. Arterial and central venous blood samples for the arterial-venous oxygen difference calculations were drawn just before the measurement of cardiac output.

All data were analysed with the two-tailed Student's $t$ test. ${ }^{35}$ The $t$ test for the non-paired variables was used when comparing inter-group oxprenolol and propranolol differences, while the data comparing values before and after beta-blockade within a single group were analysed with the $t$ test for paired variables.

\section{Results}

All outpatient blood pressure readings taken at the end of the five week beta-blockade with either drug were significantly lower in comparison with the control values, the difference between the two sets of values achieving a statistical significance with both drugs. The pretreatment outpatient systolic and diastolic blood pressures were $168 \pm 15$ and $109 \pm 8 \mathrm{mmHg}$ for oxprenolol, and $164 \pm 14$ and $105 \pm 6 \mathrm{mmHg}$ for propranolol. After five weeks on the respective beta-antagonist, the oxprenolol group reduced its systolic and diastolic blood pressures to $144 \pm 15$ and $91 \pm 11 \mathrm{mmHg}$, and the propranolol group to $139 \pm 11$ and $87 \pm 5 \mathrm{mmHg}$. All intragroup reductions in systolic and diastolic blood pressures were highly significant $(p<0.01)$. Concomitantly, no statistically significant changes between oxprenolol or propranolol groups were detectedneither at the beginning of the study, nor at the end of the beta-blockade. The supine decreases in the outpatient heart rates were also greatly lowered $(p<0.01)$ by both drugs (from $80 \pm 6$ to $59 \pm 5$ beats/min with oxprenolol, and from $85 \pm 8$ to $60 \pm 5$ beats $/ \mathrm{min}$ with propranolol), and the intergroup comparison again showed no difference between oxprenolol and prop. nolol.

The complete haemodynamic data obtained before and again at the end of the five week beta-blockade are given in Fig. 2 and 3. In contrast to a distinct decrease in systolic and diastolic blood pressure obtained on an

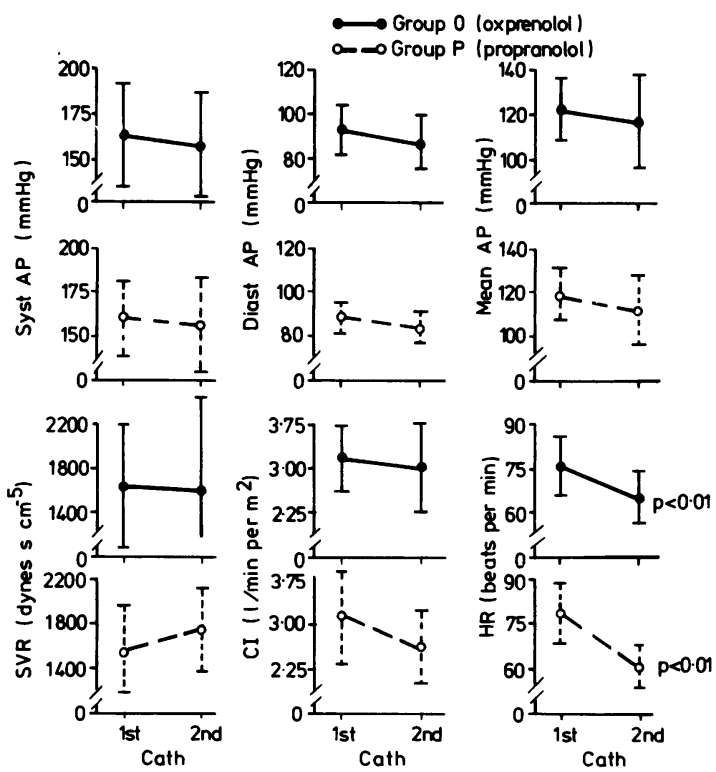

Fig. 2 Arterial pressures, systemic vascular resistance, cardiac index, and heart rate before (Ist CATH), and at the end of the five week beta-blockade (2nd CATH). (AP, arterial pressure; $C A T H$, cardiac catheterisation; $C I$, cardiac index; $H R$, heart rate; SVR, systemic vascular resistance.) Brackets in this illustration, and in Fig. 3,4, and 5 indicate one standard deviation of the mean. 

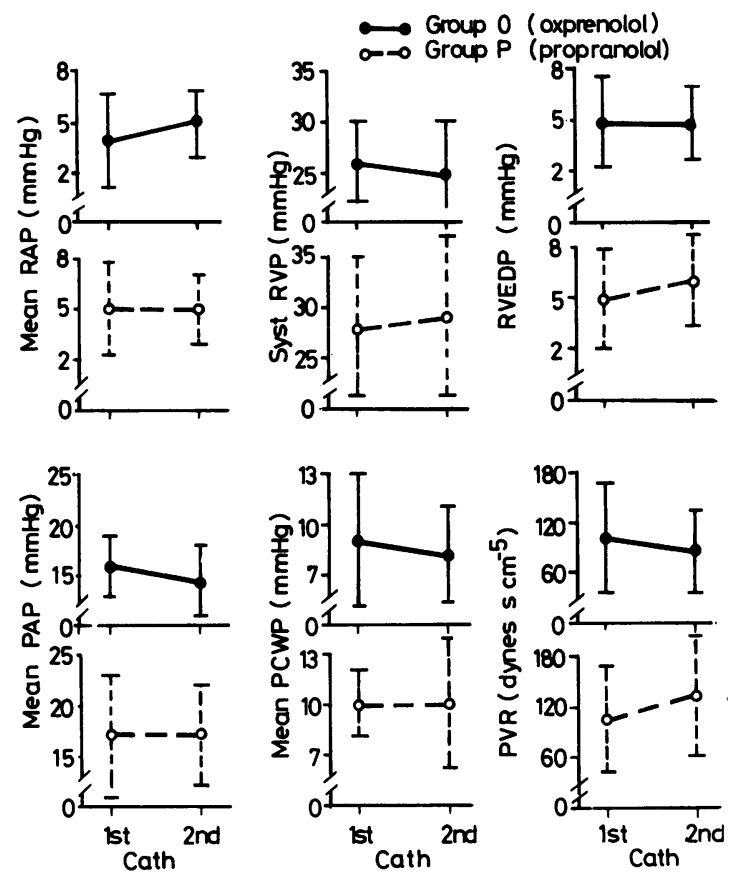

Fig. 3 Right-sided pressures and pulmonary vascular resistance before (1st CATH), and at the end of the five week beta-blockade (2ndCATH).(CATH, cardiac catheterisation; PAP, pulmonary artery pressure; $P C W P$, pulmonary capillary wedge pressure; $P V R$, pulmonary vascular resistance; $R A P$, right atrial pressure; $R V E D P$, right ventricular end-diastolic pressure; $R V P$, right ventricular pressure.)

outpatient basis after beta-blockade, the intra-arterial systolic, diastolic, and mean pressures recorded during cardiac catheterisation were lowered only slightly and insignificantly. The heart rate, however, was maintained at a much lower level $(p<0.01)$ during the second cardiac catheterisation with either oxprenolol or propranolol.

All right-sided pressures remained essentially unchanged after beta-blockade, so did the pulmonary and systemic vascular resistances. Cardiac index decreased with both drugs, but the decrease was less with oxprenolol than with propranolol. These changes, however, were not statistically significant. Moreover, the values of all variables depicted in Fig. 2 and 3 were not significantly different when oxprenolol and propranolol groups were compared with each other during the first, and again during the second cardiac catheterisation.

The arterial-venous oxygen difference, while unchanged after oxprenolol administration, was significantly higher after propranolol $(p<0.04)$ (Fig. 4). Cardiothoracic ratio increased slightly, but significantly, after beta-blockade with both drugs. Not
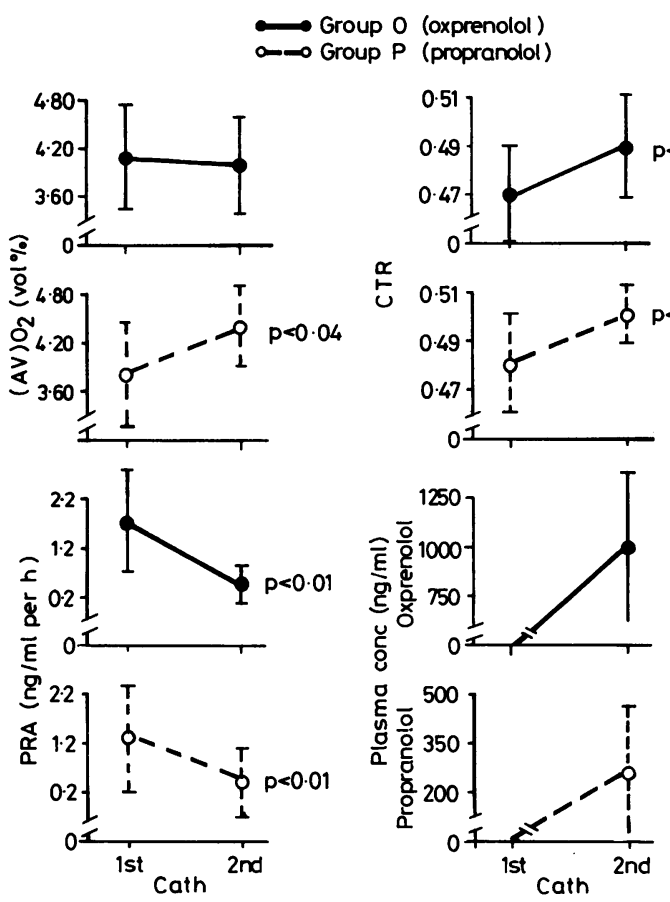

Fig. 4 Arterial-venous oxygen difference, cardiothoracic ratio, plasma concentration of oxprenolol or propranolol, and plasma renin activity before (lst CATH), and at the end of the five week beta-blockade (2nd CATH). ((AV)O ${ }_{2}$, arterial-venous oxygen difference; $C A T H$, cardiac catheterisation; CTR, cardiothoracic ratio; $P R A$, plasma renin activity.)

unexpectedly, the plasma renin activity was lowered substantially by both beta-blocking agents $(p<0.01)$, and by approximately equal margins. The administered oral doses of oxprenolol and propranolol were $418 \pm 155$ and $440 \pm 129 \mathrm{mg} /$ day, respectively (p not significant). Though both oral agents produced substantial plasma concentrations, the absolute level of plasma oxprenolol was almost five times as high as that of propranolol $(1021 \pm 393$ versus $244 \pm 210 \mathrm{ng} / \mathrm{ml}$, respectively, $\mathrm{p}<0.01)$.

Right ventricular volumetric analysis is presented in Fig. 5. The right ventricular end-diastolic volume index did not change appreciably in either the oxprenolol or the propranolol group. In contrast, the right ventricular end-systolic volume index rose significantly after betablockade with both drugs, causing a decrease in the right ventricular ejection fraction from $59 \pm 8$ to $52 \pm 12 \%$ after oxprenolol, and from $59 \pm 5$ to $54 \pm 7 \%$ after propranolol administration ( $p<0.02$ for both groups). No statistically significant difference was found when the effects of the two drugs on right ventricular volumes and ejection fraction were compared with each other. 

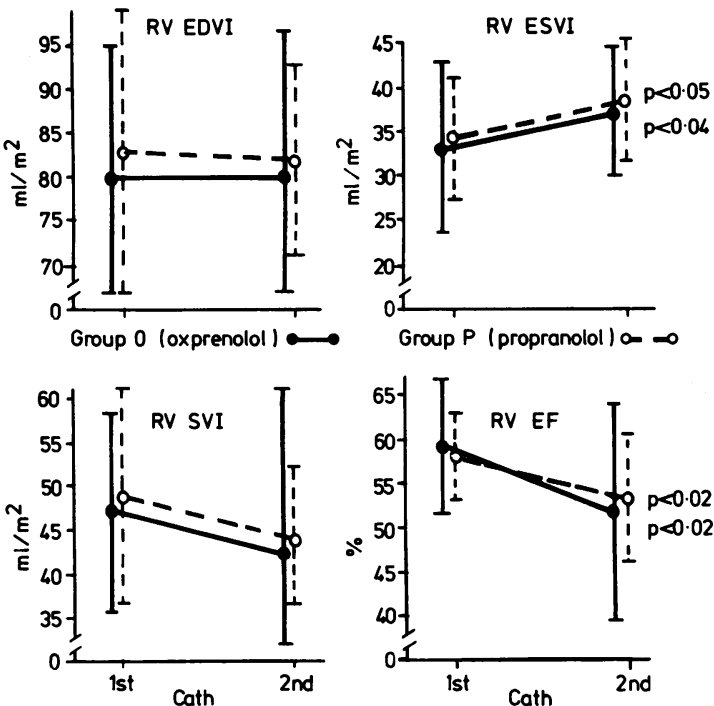

Fig. 5 Right ventricular volumes and ejection fraction before (1st CATH), and at the end of the five week beta-blockade (2nd CATH). (CATH, cardiac catheterisation; EDVI, end-diastolic volume index; $E F$, ejection fraction; $E S V I$, end-systolic volume index; SVI, stroke volume index; $R V$, right ventricular.)

\section{Discussion}

Because it has been shown that right ventricular function and right-sided pressures are abnormal even in patients with uncomplicated systemic hypertension, ${ }^{13637}$ this study was undertaken to determine if there is further depression of right ventricular performance in such subjects after beta-blockade. More than one beta-blocker was thought to be needed for such a study to obviate a possible interpretation that the effects on right-sided circulation are idiosyncratic for a particular drug, and do not represent the action of beta-blockers as a group.

Within the past decade, several new beta-adrenergic blocking agents have become available and have been investigated. Their actions are frequently compared with those of an established beta-blocker, propranolol..$^{38-41}$ The interest in oxprenolol is understandable in view of the claims that it may be as good an antihypertensive, ${ }^{42}$ antianginal, ${ }^{1921}$ and possibly antiarrhythmic ${ }^{43-45}$ agent as is propranolol, yet it possesses substantially less negative inotropic effects. ${ }^{14-1646}$ Unfortunately, some previous studies have used cardiac output as an index of myocardial contractility, ${ }^{14}$ is ignoring the fact that the cardiac output and the contractile state of myocardium are not related in a simple manner. ${ }^{47}$ Furthermore, the extent of cardiac pathology between the two treatment groups (oxprenolol versus propranolol) has sometimes been sufficiently diverse virtually to preclude meaningful conclusions. ${ }^{14,15}$ When, in another study, an identical experimental preparation was used to compare the effects of oxprenolol and propranolol on myocardial function, the administered doses of the two drugs were sufficiently different to negate any conclusions on differences in biological action. ${ }^{48}$ Our study showed slightly smaller effects on cardiac index and arterialvenous oxygen difference with oxprenolol than with propranolol. But the difference between the drugs was not significant and no firm conclusions can be drawn relating to their relative negative inotropic properties.

Both oxprenolol and propranolol had a distinct antihypertensive effect when administered to subjects on an outpatient basis. Yet this substantial antihypertensive response was not maintained when the patients were brought to the cardiac catheterisation laboratory for a repeat examination. ${ }^{49}$ Numerous mechanisms have been evoked to explain why beta-blockers lower high blood pressures. Among these are the negative inotropic effect which lowers the cardiac output, the resetting of baroreceptors, an effect mediated through the central nervous system, a decrease in renin output, a reduction in venous return or plasma volume, ${ }^{25}$ and a myogenic response of the arteriolar wall to decreased blood flow. ${ }^{50}$ While some (or most) of these mechanisms may account for the decrease in blood pressure that was observed in our subjects on the outpatient basis, they failed to maintain their antihypertensive effects when the patients were subjected to the stress of the repeat cardiac catheterisation. In contrast to the heart rates which continued to be significantly lower during the entire second haemodynamic study, the systolic, diastolic, and mean intra-arterial pressures rose to levels that were virtually identical to those observed during the first catheterisation. Thus significant stress can almost eliminate the antihypertensive effect of betablockade, but it cannot overcome its negative chronotropic effect. Similar findings were observed during our earlier study with a different beta-blocking agent, ${ }^{51}$ and were recently confirmed in a report by $\mathrm{Waal}-$ Manning. ${ }^{52}$

Both oxprenolol and propranolol conspicuously lowered the plasma renin activity after five weeks of beta-blockade, but no correlation was found between the antihypertensive effect of the two beta-blockers at cardiac catheterisation and the degree of renin suppression.

The oral doses of oxprenolol and propranolol were almost identical and the haemodynamic and volumetric effects produced by each drug were similar. Yet, the plasma level of oxprenolol was almost five times as high as that of propranolol. This large difference in plasma levels between the two drugs is probably the result of different pharmacokinetics. While propranolol undergoes extensive presystemic metabolism by the liver (the 
"first pass effect"), oxprenolol is almost completely devoid of first pass elimination. ${ }^{53}$ Furthermore, the Bio-Science assay for propranolol ${ }^{34}$ does not measure active propranolol metabolites, while the Ciba-Geigy assay for oxprenolol ${ }^{33}$ does. An active metabolite of propranolol, 4-hydroxypropranolol, was therefore not measured in this study. It is, however, equipotent to propranolol, and can achieve approximately the same circulating concentrations as the parent drug shortly after an oral dose, with effects which are added to those of propranolol. ${ }^{54} \mathrm{~A}$ simple comparison between plasma levels of oxprenolol and propranolol by the assays employed in this study can therefore not be used as an index of the bioavailability of the two drugs, or as a predictor of the cardiovascular potency of oxprenolol versus propranolol.

Ventricular ejection fraction is one of the most sensitive indices of cardiac function. ${ }^{55-57}$ In evaluating the changes induced by oxprenolol and propranolol on right ventricular performance, the volumetric right ventricular analysis - which yields ejection fraction for the two groups - was of major importance, and is the cornerstone of this study. Both beta-blockers adversely affected right ventricular function of hypertensive patients by significantly decreasing the right ventricular ejection fraction. Oxprenolol produced a similar degree of depression of right ventricular contractility as propranolol, and therefore cannot be considered to have substantially less negative inotropic properties than propranolol. The intrinsic sympathomimetic activity of oxprenolol must therefore be relatively weak.

This study, therefore, shows that in hypertensive patients the right ventricular contractility is clearly diminished after the institution of beta-blockade with two agents-an effect that has until now been thought to be limited to the left side of the heart. Great caution must therefore be exercised when beta-blockade is initiated in patients with conspicuously abnormal right ventricular function, because frank right ventricular decompensation may result. If overt right ventricular decompensation is already present the administration of beta-blocking drugs should probably be avoided.

The authors thank Ms. Kathleen Mellars for statistical analysis. Oxprenolol and propranolol were supplied by the Ciba-Geigy Corporation, Summit, New Jersey.

\section{References}

1 Ferlinz J. Right ventricular performance in essential hypertension. Circulation 1980; 61: 156-62.

2 Wolfson S, Gorlin R. Cardiovascular pharmacology of propranolol in man. Circulation 1969; 40: 501-11.

3 Goldstein RE, Hall CA, Epstein SE. Comparison of relative inotropic and chronotropic effects of propranolol, practolol, and sotalol. Chest 1973; 64: 619-27.

4 Ludbrook P, Karliner JS, Kostuk W, O'Rourke RA.
Effects of intravenously administered propranolol on wall motion abnormalities. Am $\mathcal{~}$ Cardiol 1973; 31: 712-7.

5 Coltart DJ, Alderman EL, Robison SC, Harrison DC. Effect of propranolol on left ventricular function, segmental wall motion, and diastolic pressure-volume relation in man. Br Heart $\mathcal{F} 1975$; 37: 357-64.

6 Shubrooks SJ, Zir LM, Dinsmore RE, Harthorne JW. Left ventricular wall motion response to intravenous propranolol. Circulation 1975; 52: 124-9.

7 Dwyer EM Jr, Wiener L, Cox JW. Effects of betaadrenergic blockade (propranolol) on left ventricular hemodynamics and the electrocardiogram during exercise-induced angina pectoris. Circulation 1968; 38: 250-60.

8 Helfant RH, Herman MV, Gorlin R. Abnormalities of left ventricular contraction induced by beta adrenergic blockade. Circulation 1971; 43: 641-7.

9 Frishman W, Smithen C, Befler B, Kligfield P, Killip T. Noninvasive assessment of clinical response to oral propranolol therapy. Am $\mathcal{F}$ Cardiol 1975; 35: 635-44.

10 Fitzgerald JD. Perspectives in adrenergic beta-receptor blockade. Clin Pharmacol Ther 1969; 10: 292-306.

11 Dollery CT, Paterson JW, Conolly ME. Clinical pharmacology of beta-receptor blocking drugs. Clin Pharmacol Ther 1969; 10: 765-99.

12 McDevitt DG, Brown HC, Carruthers SG, Shanks RG. Influence of intrinsic sympathomimetic activity and cardioselectivity on beta adrenoreceptor blockade. Clin Pharmacol Ther 1977; 21: 556-66.

13 Dobbs W, Povalski HJ. Coronary circulation, angina pectoris, and antianginal agents. In: Antonaccio MJ, ed. Cardiovascular pharmacology. New York: Raven Press, 1977: 461-521.

14 Grandjean T, Rivier JL. Cardio-circulatory effects of beta-adrenergic blockade in organic heart disease. Comparison between propranolol and CIBA 39,089-Ba. $\mathrm{Br}$ Heart F 1968; 30: 50-9.

15 Rivier JL, Nissiotis E, Jaeger M. Comparison of immediate haemodynamic effects of three beta-adrenergic blocking agents. Postgrad Med $\mathcal{F}$ 1970; 46, suppl: 44-9.

16 Choquet Y, Capone RJ, Mason DT, Amsterdam EA, Zelis R. Comparison of the beta adrenergic blocking properties and negative inotropic effects of oxprenolol and propranolol in patients (abstract). Am F Cardiol 1972; 29: 257.

17 Majid PA, Sharma B, Saxton C, Stoker JB, Taylor SH. Haemodynamic effects of oxprenolol in hypertensive patients. Postgrad Med 7 1970; 46, suppl: 67-72.

18 Lecerof H, Malmborg RO. Hemodynamic effects of oxprenolol alone and combined with nitroglycerin in patients with ischemic heart disease. Acta Med Scand 1972; 192: 499-506.

19 Prichard BNC, Aellig WH, Richardson GA. The action of intravenous oxprenolol, practolol, propranolol and sotalol on acute exercise tolerance in angina pectoris: the effect on heart rate and the electrocardiogram. Postgrad Med $\mathcal{f}$ 1970; 46, suppl: 77-85.

20 Robson RH, Fluck DC. Autonomic blockade and coronary catecholamines and cyclic AMP in exercising man. F Appl Physiol 1977; 43: 949-52.

21 Prichard BNC. $\beta$-adrenoreceptor blocking drugs in angina pectoris. Cardiovasc Drugs 1978; 2: 85-118. 
22 Dollery CT, George C. Propranolol-ten years from introduction. Cardiovasc Clin 1974; 6: 255-68.

23 Conolly ME, Kersting F, Dollery CT. The clinical pharmacology of beta-adrenoceptor-blocking drugs. Prog Cardiovasc Dis 1976; 19: 203-34.

24 Yin FCP, Raizes GS, Guarnieri T, et al. Age-associated decrease in ventricular response to haemodynamic stress during beta-adrenergic blockade. Br Heart $\mathcal{f} 1978$; 40: 1349-55.

25 Simpson FO. $\beta$-adrenoreceptor blocking drugs in hypertension. Cardiovasc Drugs 1978; 2: 55-83.

26 Ferlinz J. Measurements of right ventricular volumes in man from single plane cineangiograms. A comparison to the biplane approach. Am Heart f 1977; 94: 87-90.

27 Haber E, Koerner T, Page LB, Kliman B, Purnode A. Application of a radioimmunoassay for angiotensin I to the physiologic measurements of plasma renin activity in normal human subjects. F Clin Endocrinol Metab 1969; 29: 1349-55.

28 Chidsey CA, Morselli P, Bianchetti G, Morganti A, Leonetti G, Zanchetti A. Studies of the absorption and removal of propranolol in hypertensive patients during therapy. Circulation 1975; 52: 313-8.

29 Vervloet E, Pluym BFM, Cilissen J, Köhlen K, Merkus FWHM. Propranolol serum levels during twenty-four hours. Clin Pharmacol Ther 1977; 22: 853-7.

30 Walle T, Conradi EC, Walle UK, Fagan TC, Gaffney TE. The predictable relationship between plasma levels and dose during chronic propranolol therapy. Clin Pharmacol Ther 1978; 24: 668-77.

31 Shand DG. Pharmacokinetic properties of the $\beta$-adrenoreceptor blocking drugs. Cardiovasc Drugs 1978; 2: 41-54.

32 Mason WD, Winer N. Pharmacokinetics of oxprenolol in normal subjects. Clin Pharmacol Ther 1976; 20: 401-12.

33 Degen PH, Riess W. Simplified method for the determination of oxprenolol and other $\beta$-receptor blocking agents in biological fluids by gas-liquid chromatography. f Chromatogr 1976; 121: 72-5.

34 Simon M, Babich-Armstrong $\mathbf{M}$, Beardslee R. Propranolol in serum by high pressure liquid chromatography (abstract). Mexico City: Abstracts of X International Congress of Clinical Chemistry, 1978, 88.

35 Colton T. Inference on means. In: Statistics in medicine. Boston: Little Brown, 1974: 99-150.

36 Atkins JM, Mitchell HC, Pettinger WA. Increased pulmonary vascular resistance with systemic hypertension. Effect of minoxidil and other antihypertensive agents. $\mathrm{Am}$ f Cardiol 1977; 39: 802-7.

37 Olivari MT, Fiorentini C, Polese A, Guazzi MD. Pulmonary hemodynamics and right ventricular function in hypertension. Circulation 1978; 57: 1185-90.

38 Coltart DJ. Comparison of effects of propranolol and practolol on exercise tolerance in angina pectoris. $\mathrm{Br} \mathrm{Heart}$ f 1971; 33: 62-4.

39 Sniderman AD, Marpole DGF, Fallen EL. Differences between the effects of practolol and propranolol on the diastolic properties of the left ventricle. Clin Pharmacol Ther 1977; 21: 267-71.

40 Stephens J, Hayward R, Ead H, Adams L, Hamer J, Spurrell R. Effects of selective and non-selective betaadrenergic blockade on coronary dynamics in man asses- sed by rapid atrial pacing. Br Heart $\mathcal{Y} 1978$; 40: 856-63.

41 Turner GG, Nelson RR, Nordstrom LA, Diefenthal HC, Gobel FL. Comparative effect of nadolol and propranolol on exercise tolerance in patients with angina pectoris. $\mathrm{Br}$ Heart $\mathcal{F}$ 1978; 40: 1361-70.

42 Andersson O, Berglund G, Bergman H, et al. Antihypertensive effect and side-effects of treatment with beta blockers-a comparative study between oxprenolol and propranolol. Curr Ther Res 1976; 19: 43-50.

43 Mason DT, DeMaria AN, Amsterdam EA, et al. Antiarrhythmic agents: mechanisms of action, clinical pharmacology and therapeutic considerations. Cardiovasc Drugs 1978; 1: 75-133.

44 Singh BN, Lewitt DE. $\beta$-adrenoreceptor blocking drugs in cardiac arrhythmias. Cardiovasc Drugs 1978; 2: 119-59.

45 DiBase M, Guglielmi R, Scarcia A, Chiddo A, Rizzon P. Electrophysiologic properties of intravenous oxprenolol in man. Electrocardiology 1977; 10: 267-73.

46 Marshall AJ, Barritt DW. Oxprenolol in hypertension. $\mathrm{Br}$ f Clin Pract 1973; 27 : 337-40.

47 Braunwald E. On the difference between the heart's output and its contractile state. Circulation 1971; 43: 171-4.

48 Nayler WG. Myocardial function during $\beta$-adrenergic blockade. Isr F Med Sci 1969; 5: 741-6.

49 Ferlinz J, Easthope JL, Hughes D, Siegel J, Tobis J, Aronow WS. Antihypertensive and hemodynamic effects of oxprenolol versus propranolol. Clin Pharmacol Ther 1980; $27: 733-43$.

50 Frohlich ED, Lohmöller G. A comparison of timolol and propranolol in hypertension. In: Magnani B, ed. Betaadrenergic blocking agents in the management of hypertension and angina pectoris. New York: Raven Press, 1974: 45-58.

51 Aronow WS, Ferlinz J, Del Vicario M, Moorthy K, King $\mathrm{J}$, Cassidy J. Effect of timolol versus propranolol on hypertension and hemodynamics. Circulation 1976; 54: 47-51.

52 Waal-Manning HJ. Atenolol and three nonselective $\beta$ blockers in hypertension. Clin Pharmacol Ther 1979; 25: 8-18.

53 Riess W, Brechbühler S, Brunner L, Imhof PR, Jack DB. The metabolism of beta-blockers in relation to their pharmacokinetic and pharmacodynamic behavior. In: Schweizer W, ed. Beta blockers-present status and future prospects. Berne: Hans Huber, 1974: 276-89.

54 Nies AS, Shand DG. Clinical pharmacology of propranolol. Circulation 1975; 52: 6-15.

55 Kreulen TH, Bove AA, McDonough MT, Sands MJ, Spann JF. The evaluation of left ventricular function in man. A comparison of methods. Circulation 1975; 51: 677-88.

56 Tynan M, Reid DS, Hunter S, et al. Ejection phase indices of left ventricular performance in infants, children, and adults. Br Heart $\mathcal{F}$ 1975; 37: 196-202.

57 Rackley CE. Quantitative evaluation of left ventricular function by radiographic techniques. Circulation 1976; 54: 862-79.

Requests for reprints to Dr Jack Ferlinz, Cardiac Catheterization Laboratory, Long Beach VA Medical Center, 5901 East Seventh Street, Long Beach, California 90822, USA. 